\title{
THE EFFECTS OF SINGLE HIGH DOSE VERSUS DAILY LOW DOSE ORAL CHOLECALCIFEROL TREATMENT ON VITAMIN D LEVELS AND MUSCLE STRENGHT IN POSMENAPOUSAL WOMEN
}

\footnotetext{
${ }^{1}$ Diskapi Yildirim Beyazit Teaching and Research Hospital, Department of Endocrinology and Metabolism, Ankara, Turkey

${ }^{2}$ Hacettepe University, School of Medicine (Kastamonu), Department of Internal Medicine, Ankara, Turkey

${ }^{3}$ Diskapi Yildirim Beyazit Teaching and Research Hospital, Department of Physical Medicine and Rehabilitation, Ankara, Turkey
}

\section{Objectives:}

\section{Methods:}

\section{Results:}

References:

\section{Conclusions:}

Although daily administration routes are effective in muscle strength, single administration is more

Vitamin D deficiency is a common health problem. Vitamin D supplements are used to improve vitamin $\mathrm{D}$ status. However, there are few data about what doses to give and how often to give. The aim of this study is to determine the effects of single high dose or daily low dose oral cholecalciferol (vitamin D3) on vitamin D levels and muscle strenght.

60 healthy postmenouposal women who had serum vitamin D levels were less than $20 \mathrm{ng} / \mathrm{ml}$ were enrolled in the study in the winter and spring of 2013 to 2014 . First group $(n=32)$ was given daily oral doses of 800 IU vitamin D3, second group ( $n=28$ ) was given single oral dose of 300.000 IU vitamin D3. Serum vitamin $D$ levels and muscle strengths were measured at the beginnig, $4^{\text {th }}$ and $12^{\text {th }}$ weeks. Muscle strength tests were performed at $60^{\circ} \mathrm{lsec}$ with Biodex system 3 isokinetic dynamometer.

The mean vitamin $D$ levels of first and second group at the beginnig were $10,2 \pm 4,4 \mathrm{ng} / \mathrm{ml} ; 9,7 \pm 4,4$ $\mathrm{ng} / \mathrm{ml}(\mathrm{p}=0,637)$, respectively. Significant increase in vitamin $D$ levels was measured in both two groups at 4 and 12 weeks after vitamin D3 treatment. At $4^{\text {th }}$ week the increase in single dose of vitamin D3 group $(35,9 \pm 9,6 \mathrm{ng} / \mathrm{ml})$ was significantly higher than the daily low dose oral vitamin D3 group $(16,9 \pm 5,8 \mathrm{ng} / \mathrm{ml})(p=0,01)$. At $12^{\text {th }}$ week the increase in single dose of vitamin D3 group $(23,4 \pm 4,7)$ was significantly higher than the daily low dose oral vitamin D3 group $(19,8 \pm 7,2$ $\mathrm{ng} / \mathrm{ml})(\mathrm{p}=0,049)$. Quadriceps muscle strength score increased significantly in daily group at $4^{\text {th }}$ week. Hamstring muscle strength score increase significantly in daily group at $12^{\text {th }}$ week.

\footnotetext{
effective in increasing vitamin D levels.
}

Mahmut Apaydin ${ }^{1}$, Asli Gencay Can ${ }^{3}$, Selvihan Beysel ${ }^{1}$, Seyfullah Kan ${ }^{1}$, Taner Demirci ${ }^{1}$, Mustafa Caliskan ${ }^{1}$, Muhammed Kizilgul, Ozgur Ozcelik, Muyesser Sayki Arslan ${ }^{1}$, Mustafa Ozbek ${ }^{1}$, Erman Cakal ${ }^{1}$, Tuncay Delibasi ${ }^{1,2}$ 